DOI: https://doi.org/10.31933/jimt.v2i3

Received: 1 November2020, Revised: 25 Desember 2020, Publish: 8 Februari 2021

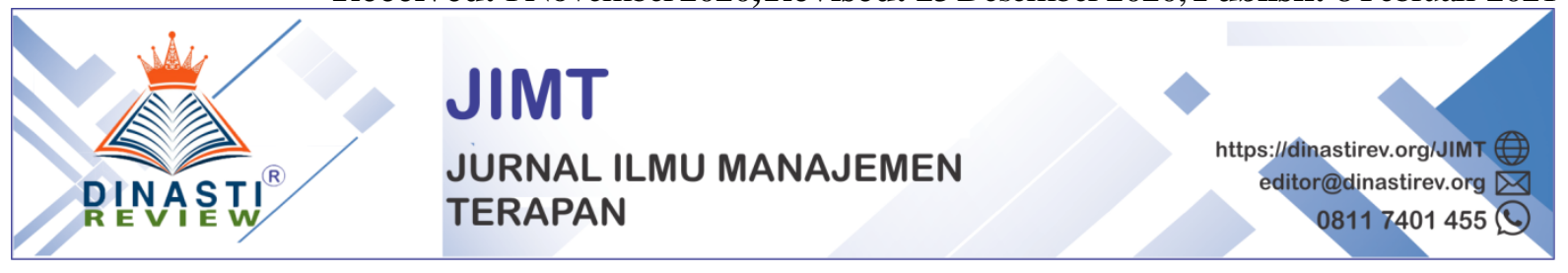

\title{
LITERATURE REVIEW DETERMINASI MOTIVASI DAN KINERJA: ANALISIS KOMPENSASI (BONUS) DAN PROMOSI JABATAN (STUDY PADA PT.SDS)
}

\author{
Nico Gunawan \\ Mahasiswa Program Magister Manajemen Sumber Daya Manusia, Universitas Terbuka, \\ Dumai, Nico_gunawan@ rocketmail.com
}

Corresponding Author: Nico Gunawan

Abstrak: Pra riset ini dilakukan bertujuan untuk membangun hipotesis penelitian dengan menggunakan motode deskriptif. Untuk mengetahui pengaruh dari kompensasi (bonus) dan promosi jabatan terhadap motivasi dan kinerja karyawan. Hasil dari literature review ini adalah hipotesis yang akan digunakan dalam riset selanjutnya oleh penulis.

Kata Kunci: Bonus, Kinerja, Kompensasi, Motivasi, Promosi

\section{PENDAHULUAN}

Sumber daya manusia atau human recources mengandung dua pengertian. Pertama, adalah usaha kerja atau jasa yang dapat diberikan dalam proses produksi. Dalam hal lain SDM mencerminkan kualitas usaha yang diberikan oleh seseorang dalam waktu tertentu untuk menghasilkan barang dan jasa. Pengertian kedua, SDM menyangkut manusia yang mampu bekerja untuk memberikan jasa atau usaha kerja tersebut. Mampu bekerja berarti mampu melakukan kegiatan yang mempunyai kegiatan ekonomis, yaitu bahwa kegiatan tersebut menghasilkan barang atau jasa untuk memenuhi kebutuhan atau masyarakat (sumarsono, 2003). Dengan terbatasnya sumber daya manusia yang ada, organisasi diharapkan dapat mengoptimalkannya sehingga tercapai tujuan organisasi yang telah ditetapkan. Sumber daya manusia merupakan bagian dari dalam suatu kemajuan ilmu dan teknologi, dimana dibutuhkan sumber daya manusia yang kompeten dengan semangat dan disiplin tinggi untuk dapat bersaing di era globalisasi ini.

PT. Sari Dumai Sejati (SDS) merupakan unit bisnis APICAL group yang bergerak dibidang komodity minyak kelapa sawit dan turunannya (Apicalgroup.com, 2020). Perusahaan ini berlokasi di dumai dengan beberapa bagian operasional seperti Refinery Plant, Fractionation Plant, Spliting Plant, Kernel Crushing Plant, Biodiesel Plant, dan Oleochemical Plant. Perusahaan ini merupakan salah satu exportir minyak kelapa sawit terbesar di indonesia. Penilaian kinerja PT.SDS dilakukan sebanyak 2 kali dalam setahun dimana periode penilaian dilakukan untuk januari-juni dan juli-desember. Penilaian kinerja yang dilakukan dalam dua periode akan dijadikan satu dan diumumkan pada bulan April setiap tahunnya. Hasil penilaian tahunan karyawan menentukan tingkat bonus yang diterima oleh karyawan. Pemberian bonus perusahaan dilakukan sebanyak dua kali dimana dilakukan pada bulan April dan Oktober setiap tahunnya. Di bulan yang sama juga perusahaan melakukan 
promosi bagi karyawan yang telah lolos seleksi. Pemberian promosi jabatan ini juga berdasarkan hasil dari kinerja karyawan tersebut.

Artikel ini khusus membahas pengaruh kompensasi (bonus) dan promosi jabatan terhadap motivasi dan dampaknya terhadap kinerja, Tentu tidak semua faktor yang mempengaruhi Motivasi Kerja dan Kinerja Karyawan pada artikel ini, ini hanya sebagian kecil saja yang akan di kaji dan di review.

Secara rinci tujuan dari penulisan "Literature Review Paper" ini adalah mengetahui pengaruh atau hubungan antara variabel exogen kompensasi (bonus) dan promosi jabatan terhad ap variabel endogen motivasi dan kinerja.

1) Pengaruh atau hubungan kompensasi (bonus) terhadap motivasi

2) Pengaruh atau hubungan promosi jabatan terhadap motivasi

3) Pengaruh atau hubungan kompensasi (bonus) terhadap kinerja

4) Pengaruh atau hubungan promosi jabatan terhadap kinerja

5) Pengaruh atau hubungan motivasi terhadap kinerja

\section{KAJIAN PUSTAKA}

Kinerja

Menurut Simamora (2006) Penilaian kinerja adalah proses yang dipakai oleh organisasi untuk mengevaluasi pelaksanaan kerja individu karyawan. dalam penilaian kinerja dinilai kontribusi karyawan kepada organisasi selama periode waktu tertentu

Menurut Rivai (2008) Penilaian kinerja adalah hasil kerja yang dapat dicapai oleh seseorang atau kelompok orang dalam suatu perusahaan atau organisasi sesuai dengan wewenang dan tanggung jawab masing -masing dalam upaya pencapaian tujuan perusahaan secara legal, tidak melanggar hukum dan bertentangan dengan etika. Sementara itu menurut Jaya (2012) fungsi interaksi antara kemampuan atau Ability (A), motivasi atau Motivation(M) dan kesempatan atau oppotunity

Menurut Sofyan (2013) istilah kinerja digunakan untuk mengukur hasil yang telah dicapai sehubungan dengan kegiatan atau aktivitas perusahaan, apakah kinerja perusahaan telah baik atau perlu adanya evaluasi-evaluasi kebelakang mengenai hasil yang dicapai. Sedangkan menurut Wartono (2017) Kinerja karyawan adalah hasil kerja yang dicapai seseorang atau kelompok orang sesuai dengan wewenang/tanggung jawab masing-masing karyawan selama periode tertentu. Sebuah perusahaan perlu melakukan penilaian kinerja pada karyawannya.

Berdasarkan pengertian diatas dapat ditarik kesimpulan bahwa kinerja adalah evaluasi yang dilakukan untuk mengukur hasil kerja individu dalam suatu organisasi yang merupakan interaksi dari kemampuan, motivasi dan kesempatan.

\section{Motivasi}

McShane (2010) dalam Ridho (2019) mendefinisikan motivasi sebagai " the forces within a person that affect the direction, intensity,and persistence of voluntary behavior ", yang kurang lebih berarti menggambarkan motivasi sebagai kekuatan dalam diri seseorang yang mempengaruhi arah, intensitas, dan ketekunan perilaku secara sukarela

Munandar (2001) mendefinisikan motivasi sebagai proses dimana kebutuhankebutuhan mendorong seseorang untuk melakukan serangkaian pekerjaan yang mengarah ke tercapainya tujan tertentu. Sementara itu menurut Omollo (2015) Motivasi adalah kunci dari organisasi yang sukses untuk menjaga kelangsungan pekerjaan dalam organisasi dengan cara dan bantuan yang kuat untuk bertahan hidup. Motivasi adalah memberikan bimbingan yang tepat atau arahan, sumber daya dan imbalan agar mereka terinspirasi dan tertarik untuk bekerja dengan cara yang anda inginkan. 
Menurut Maduka (2014) Motivasi adalah proses membangkitkan perilaku, mempertahankan kemajuan perilaku, dan menyalurkan perilaku tindakan yang spesifik. Dengan demikian, motif (kebutuhan, keinginan) mendorong karyawan untuk bertindak. Sedangkan menurut Anoraga (2009) Motivasi dikatakan sebagai kebutuhan yang mendorong perbuatan kearah suatu tujuan tertentu Motivasi kerja adalah suatu yang menimbulkan semangat atau dorongan kerja. Oleh sebab itu, motivasi kerja dalam psikologi kerya biasa disebut pendorong semangat kerja. Kuat dan lemahnya motivasi kerja seorang tenaga kerja ikut menentukan besar kecilnya prestasinya

Berdasarkan pengertian diatas dapat ditarik kesimpulan bahwa Motivasi adalah dorongan kekuatan dalam diri seseorang yang mempengaruhi hasil kerjanya.

\section{Promosi Jabatan}

Menutur Manullang (2006) promosi jabatan adalah penaikan jabatan, yakni menerima kekuasaan dan tanggung jawab Iebih besar dari kekuasaan dan tanggung jawab sebelumnya.

Menurut Siagian (2015) promosi adalah apabila seorang karyawan dipindahkan dari satu pekerjaan ke pekerjaan lain yang tanggung jawabnya Iebih besar, tingkatannya dalam hierarki jabatan lebih tinggi dan penghasilannya pun lebih besar pula. Sementara itu menurut Mondy (2008) promosi adalah perpindahan seseorang ke sebuah posisi pada level yang Iebih tinggi dalam organisasi

Menurut Jacson (2006) promosi jabatan adalah perpindahan seseorang ke tingkat pekerjaan dan kompensasi yang lebih tinggi termasuk dalam proses seleksi. Sedangkan menurut Swasto (2011) menyatakan bahwa promosi merupakan perpindahan dari satu jabatan ke jabatan lain yang lebih tinggi sebagai imbalan karena prestasi kerjanya yang baik, masa kerjanya yang lama dan lainnya.

Berdasarkan pengertian diatas dapat ditarik kesimpulan bahwa promosi jabatan adalah proses perpindahan tingkat pekerjaan seseorang ke posisi yang lebih tinggi dengan beban kerja yang lebih besar dari sebelumnya melalui seleksi seperti prestasi kerja, masa kerja dan lainnya.

\section{Pengertian Bonus}

Menurut Priansa (2016) bonus merupakan uang yang dibayarkan sebagai balas jasa atas hasil pekerjaan yang telah dilaksanakan, diberikan selektif dan khusus kepada pekerja yang berhak menerimanya, serta diberikan berkala, sakali terima tanpa adanya suatu ikatan pada masa yang akan datang.

Menurut Kasmir (2016) Bonus merupakan pembayaran yang dilakukan kepada seseorang karena prestasinya atau prestasi perusahaan secara keseluruhan. Sementara itu menurut Mubarok (2017) Bonus merupakan insentif individual yang merupakan imbalan yang diberikan untuk usaha dan kinerja secara individu dalam bekerja.

Menurut Sofyandi (2008) Bonus merupakan konpensasi secara langsung oleh perusahaan berkaitan dengan pekerjaan yang dilakukan oleh karyawan. Sedangkan menurut Sedarmayanti (2007) Bonus hasil produksi insentif yang dibayarkan kepada karyawan karena berhasil malampaui target.

Berdasarkan pengertian diatas dapat ditarik kesimpulan bahwa bonus merupakan kompensasi langsung yang diterima berdasarkan prestasi karyawan dan prestasi perusahaan tanpa ada ikatan untuk masa yang akan datang.

\section{METODE PENELITIAN}


Metode penulisan artikel ilmiah ini adalah dengan metode kualitatif dan studi literature atau Library Research. Mengkaji Buku-buku literature sesuai dengan teori yang di bahas khusunya di lingkup Manajemen Sumberdaya Manusia (MSDM). Disamping itu menganalisis artikel-artikel ilmiah yang bereputasi dan juga artikel ilmiah dari jurnal yang belum bereputasi. Semua artikel ilmiah yang di citasi bersumber dari Mendeley dan Scholar Google.

Dalam penelitian kualitatif, kajian pustaka harus digunakan secara konsisten dengan asumsi-asumsi metodologis. Artinya harus digunakan secara induktif sehingga tidak mengarahkan pertanyaan-pertanyaan yang diajukan oleh peneliti. Salah satu alasan utama untuk melakukan penelitian kualitatif yaitu bahwa penelitian tersebut bersifat eksploratif, (Ali \& Limakrisna, 2013).

Selanjutnya dibahas secara mendalam pada bagian yang berjudul" Pustaka Terkait" (Related Literature) atau Kajian pustaka( "Review of Literature"), sebagai dasar perumusan hipotesis dan selanjutnya akan menjadi dasar untuk melakukan perbandingan dengan hasil atau temuan-temuan yang terungkap dalam penelitian, (Ali \& Limakrisna, 2013).

\section{Pembahasan}

a. Pengaruh bonus terhadap motivasi karyawan.

Berdasarkan hasil penelitian Farhana (2016) ditemukan bahwa pembagian gaji yang sesuai dengan prinsip syariah mempengaruhi secara signifikan motivasi kerja pegawai, danpemberian bonus yang sesuai dengan prinsip syariah mempengaruhi secara signifikanmotivasi kerja pegawai, serta gaji dan bonus yang sesuai prinsip syariah secara simultan juga mampu mempengaruhi secara signifikan motivasi kerja pegawai pada Dinas Pendidikan Provinsi Sulawesi Selatan. Sementara itu Hasil penelitian Fauziah (2016) menunjukkan bahwa kompensasi langsung termasuk bonus memiliki pengaruh yang signifikan terhadap motivasi kerja karyawan. Sedangkan menurut Afrida (2014) secara keseluruhan variabel kompensasi baik finansial maupun non finansial yang diterapkan di PT. Ekamas Fortuna Malang untuk meningkatkan motivasi dan kinerja karyawan sudah baik.

b. Pengaruh bonus terhadap kinerja karyawan

Menurut penelitian Fauziah (2016) kompensasi langsung berpengaruh signifikan terhadap kinerja karyawan. Sementara itu berdasarkan hasil analisis penelitian Setiawan (2014) terbukti bahwa kompensasi dan lingkungan kerja berpengaruh positif dan signifikan secara langsung terhadap kinerja karyawan CV. Berkat Anugrah. Sedangkan menurut Afrida (2014) kompensasi finansial, kompensasi non finansial, dan motivasi kerja memiliki pengaruh signifikan terhadap kinerja karyawan

c. Pengaruh promosi jabatan terhadap motivasi karyawan

Penelitian yang dilakukan oleh Prabowo (2016) menyebutkan promosi jabatan karyawan berpengaruh signifikan terhadap motivasi kerja karyawan. sementara itu menurut Putra (2010) promosi jabatan mempunyai hubungan yang cukup kuat dengan motivasi kerja karyawan pada PT. BPR Sinar Mas Pelita. Sedangkan menurut Fahmi (2001) Dengan adanya promosi jabatan maka kebutuhan untuk mengaktualisasikan diri terpenuhi dan ini akan memotivasi pekerja untuk bekerja lebih baik lagi.

d. Pengaruh promosi jabatan terhadap kinerja karyawan

Penelitian yang dilakukan oleh Rahayu (2017) menyebutkan promosi jabatan berpengaruh positif dan signifikan terhadap kinerja karyawan PT. Garuda Metalindo. Sementara itu menurut Septiani (2015) hasil penelitian menunjukan bahwa promosi jabatan 
secara simultan maupun parsial berpengaruh signifikan terhadap kinerja karyawan. Sedangkan menurut Martina (2017) berdasarkan hasil penelitian dapat diketahui bahwa promosi jabatan berpengaruh signifikan terhadap kinerja karyawan PT Tasma Puja di Pekanbaru. Dengan analisis regresi sederhana bertanda positif yang artinya jika promosi jabatan meningkat maka kinerja karyawan meningkat.

a. Pengaruh motivasi terhadap kinerja karyawan

Penelitian yang dilakukan oleh Prabowo (2016) menyebutkan Motivasi kerja karyawan berpengaruh signifikan terhadap prestasi kerja karyawan. Sementara itu menurut Kasenda (2013) Motivasi berpengaruh signifikan terhadap kinerja karyawan Sedangkan menurut Jayusman (2016) variabel motivasi mempunyai pengaruh secara signifikan terhadap kinerja pegawai;

\section{Conceptual Framework}

Berdasarkan rumusan masalah penulisan artikel ini dan kajian studi literature review baik dari buku dan artikel yang relevan, maka di perolah rerangka artikel ini seperti di bawah ini.

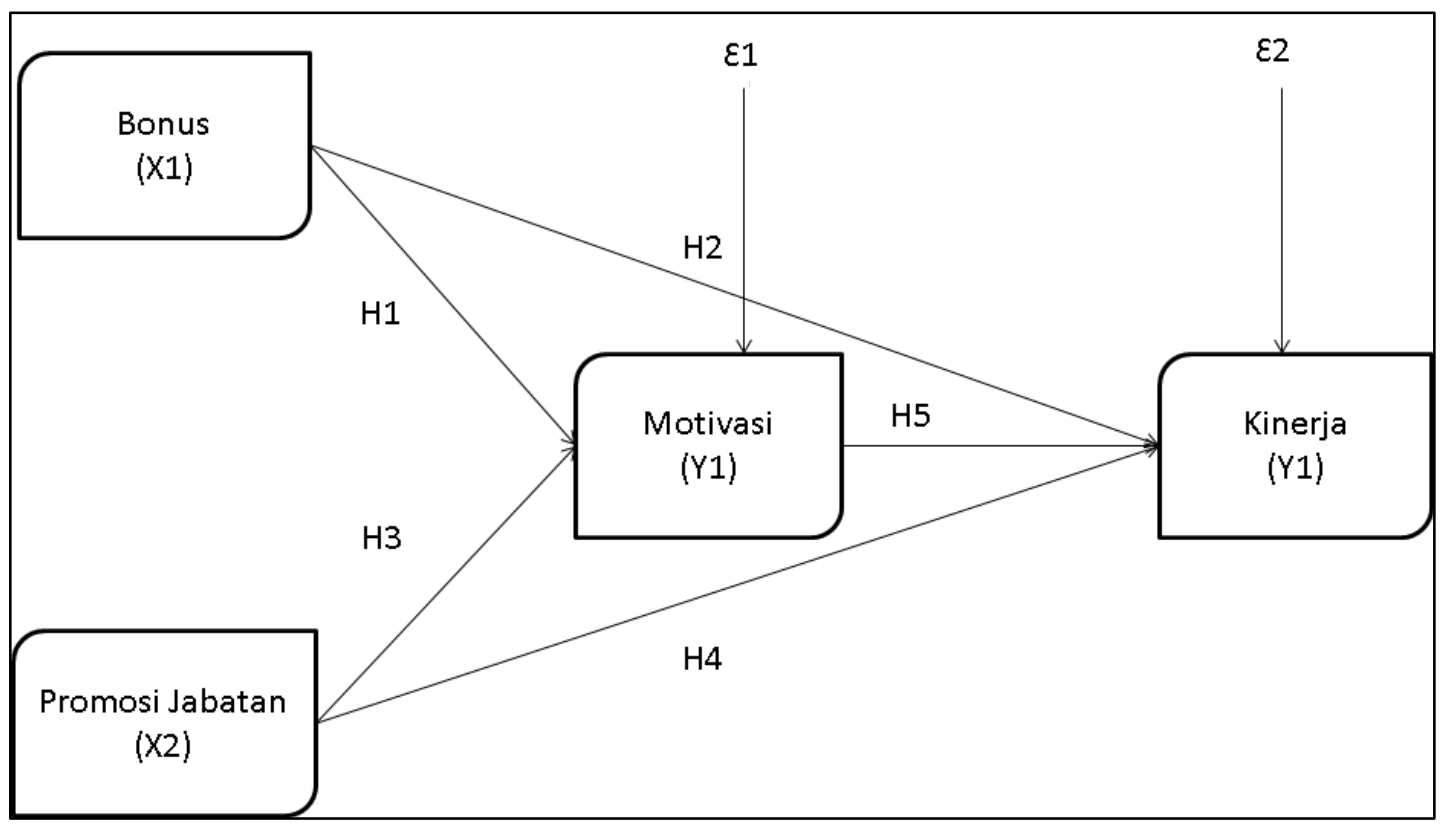

Figure 1: Conceptual Framework

Berdasarkan Kajian teori dan review hasil dari artikel yang relevan serta gambar dari conceptual framework, maka: kompensasi (bonus) dan promosi jabatan berpengaruh terhadap motivasi dan kinerja baik secara langsung maupun tidak langsung.

\section{KESIMPULAN DAN SARAN}

\section{Kesimpulan}

Berdasarkan rumusan artikel, hasil dan pembahasan, maka dapat di di rumuskan hipotesis untuk riset selanjutnya:

a. Bonus berpengaruh signifikan terhadap motivasi karyawan.

b. Bonus berpengaruh signifikan terhadap kinerja karyawan.

c. Promosi Jabatan berpengaruh signifikan terhadap motivasi karyawan.

d. Promosi Jabatan berpengaruh signifikan terhadap kinerja karyawan.

e. Motivasi berpengaruh signifikan terhadap kinerja karyawan. 


\section{Saran}

Berdasarkan Kesimpulan di atas, maka saran pada artikel ini adalah bahwa masih banyak factor lain yang mempengaruhi motivasi dan kinerja, selain dari kompenasi (bonus) dan promosi jabatan pada semua tipe dan level organisasi di PT.SDS, oleh karena itu masih di perlukan kajian yang lebih lanjut untuk mencari faktor-faktor lain apa saja yang dapat memepengaruhi motivasi dan kinerja selain yang di teliti pada arikel ini.

\section{DAFTAR PUSTAKA}

Afrida, Z. (2014). Pengaruh Kompensasi Finansial dan Non Finansial terhadap Motivasi Kerja dan Kinerja Karyawan (Studi pada Karyawan Departemen Produksi PT. Ekamas Fortuna Malang). Jurnal Administrasi Bisnis, 12(1).

Ali, H., \& Limakrisna, N. (2013). Metodologi Penelitian (Petunjuk Praktis untuk Pemecahan Masalah Bisnis, Penyusunan Skripsi, Tesis, dan Disertasi). Deeppublish: Yogyakarta

Anoraga, P. (2009). Psikologi Kerja, PT. Rineka Cipta, Jakarta.

Fahmi, F. (2001, March). Pengaruh Pendidikan dan Pelatihan Serta Promosi Jabatan Terhadap Motivasi Kerja Di Pertamina APEP Kamojang. In Proceeding Of The 5th Inaga Annual Scientific Conference \& Exhibitions (pp. 7-10).

Farhana, S. N. (2016). Pengaruh Gaji dan Bonus Terhadap Motivasi Kerja Pegawai Ditinjau dari Aspek Syariah pada Kantor Dinas Pendidikan Provinsi Sulawesi Selatan (Doctoral dissertation, Universitas Islam Negeri Alauddin Makassar).

Fauziah, S., Sunuharyo, B. S., \& Utami, H. N. (2016). Pengaruh Kompensasi Langsung dan Kompensasi Tidak Langsung Terhadap Motivasi Kerja Karyawan dan Kinerja Karyawan (Studi pada AJB Bumiputera 1912 Cabang Celaket Malang). Jurnal Administrasi Bisnis, 37 (1), 178 187.

Https://www.apicalgroup.com/our-business/operations/ (diakses tanggal 3 oktober 2020)

Jacson, M. D. (2006). Hal 262. Korelasi Positif Penempatan Pegawai dan Peningkatan Produktifitas Kerja. Perkasa.

Jaya, M. K., Mulyadi, D., \& Sulaeman, E. (2012). Pengaruh kecerdasan emosional terh adap kinerja karyawan pada kantor kementerian agama Kabupaten Karawang. Jurnal manajemen, 10(1), 1038-1046.

Jayusman, H., \& Khotimah, S. (2016). Pengaruh kepemimpinan, komunikasi, motivasi, pengembangan karir, dan promosi jabatan terhadap kinerja pegawai kantor sekretariat daerah Kabupaten Kotawaringin Barat. JURNAL ILMIAH BISNIS dan KEUANGAN, 2(2).

Kasenda, R. (2013). Kompensasi dan motivasi pengaruhnya terhad ap kinerja kary aw an pada PT. Bangun Wenang Beverages Company Manado. Jurnal EMBA: Jurnal Riset Ekonomi, Manajemen, Bisnis dan Akuntansi, 1(3).

Kasmir, D. (2016). Manajemen Sumber Daya Manusia (Teori dan Praktik). Jakarta: Rajawali Pers.

Maduka, C. E., \& Okafor, O. (2014). Effect of motivation on employee productivity: A study of manufacturing companies in Nnewi. International Journal of Managerial Studies and Research, 2(7), 137-147.

Manullang, M., \& Manullang, M. A. (2006). Manajemen Personalia. Yogyakarta.

Martina, A. B. (2017). Pengaruh Promosi Jabatan Terhadap Kinerja Karyawan Pada PT Tasma Puja Di Pekanbaru. Menara Ilmu, 11(76). 
Mondy, R. W. (2008). Sumber Daya Manusia. Jakarta: Indeks.

Mubarok, E. S. (2017). Manajemen sumber daya manusia pengantar keunggulan bersaing. Penerbit In Media, Bogor.

Munandar, A. S. (2001). Psikologi industri dan organisasi. Universitas Indonesia (UI-Press).

Omollo, P. A., \& Oloko, M. A. (2015). Effect of motivation on employee performance of commercial banks in Kenya: A case study of Kenya Commercial Bank in Migori Co unty. International journal of human resource studies, 5(2), 87-103.

Putra, Y. (2010). PENGARUH PROMOSI JABATAN TERHADAP MOTIVASI KERJA KARYAWAN PADA PT. BPR SINAR MAS PELITA.

Prabowo, B., Al Musadieq, M., \& Ruhana, I. (2016). Pengaruh Promosi Jabatan Terh ad ap Motivasi Kerja Dan Prestasi Kerja (Studi Pada Karyawan PT Telkom Indonesia Witel Jatim Selatan Malang). Jurnal Administrasi Bisnis, 32(1), 106-113.

Priansa, D. J. Suwatno (2016) Manajemen SDM dalamOrganisasiPublik dan Bisnis. Bandung: ALFABETA.

Rahayu, S. (2017). Pengaruh Promosi Jabatan terhadap Kinerja Karyawan pada PT. Garuda Metalindo. Jurnal Kreatif, 5(1).

Ridho, M., \& Susanti, F. (2019). Pengaruh Stres Kerja Dan Motivasi Kerja Terhadap Kepuasan Kerja Pada Karyawan Bank Mandiri Syariah Cabang Padang.

Rivai, V., \& Veithzal, A. P. (2008). Islamic financial management: teori, konsep dan aplikasi panduan praktis untuk lembaga keuangan, nasabah, praktisi, dan mahasiswa. Rajawali Press.

Sedarmayanti, P. (2007). Manajemen Sumber Daya Manusia. Jakarta: PT. Bumi Aksara.

Septiani, V. M. (2015). Pengaruh pelatihan, pengalaman kerja, dan promosi jabatan terhadap kinerja karyawan pada Badan Pemeriksa Keuangan Republik Indonesia perwakilan Sulawesi Utara. Jurnal EMBA: Jurnal Riset Ekonomi, Manajemen, Bisnis dan Akuntansi, 3(3).

Setiawan, F., \& Dewi, A. S. K. (2014). Pengaruh Kompensasi Dan Lingkungan Kerja Terhadap Kinerja Karyawan pada CV. Berkat Anugrah. E-Jurnal Manajemen Universitas Udayana, 3(5).

Siagian Sondang, P. (2015). Manajemen Sumber Daya Manusia Jakarta. Penerbit Bumi Aksara.

Simamora, H. (2006). Manajemen Sumber Daya Manusia, Edisi 2, STIE YKPN

Sofyan, D. K. (2013). Pengaruh Lingkungan Kerja Terhadap Kinerja Kerja Pegawai BAPPEDA. Industrial Engineering Journal, 2(1).

Sof yandi, H. (2008). Manajemen sumber daya manusia. Yogyakarta: Graha Ilmu.

Sumarsono, S. (2003). Ekonomi manajemen sumberdaya manusia dan ketenagakerjaan. Graha Ilmu.

Swasto, B. (2011). Manajemen sumber daya manusia.

Wartono, T. (2017). Pengaruh stres kerja terhadap kinerja karyawan (studi pada karyaw an majalah Mother and Baby). KREATIF: Jurnal Ilmiah Prodi Manajemen Universitas Pamulang, 4(2) 